\title{
Cytogenotoxicity effects of industrial effluents on Allium cepa root meristem: A review on positive results and problems of effective compliance to environmental legislations; the Nigeria perspective
}

\author{
Abu Ngozi E. \\ Department of Plant Science and Biotechnology, University of Nigeria, Nsukka, Nigeria. \\ E-mail: ngozi.abu@unn.edu.ng. Tel: +234-8064664555. \\ Accepted 3 December, 2012
}

\begin{abstract}
Most industries are sited with little or no consideration for environmental and social consequences, especially in developing countries. This has led to the discharge of genotoxic chemicals used for many purposes in the manufacturing processes into environmental compartments such as air, water, soil and sediments. Results of the cytotoxic and genotoxic assays of these wastewaters on Allium cepa root tip meristem showed significant reduction of mitotic indices and diverse forms of chromosomal aberrations, cytokinetic failures, micro and multiple nuclei. In Nigeria, the results of diverse assessments of industrial effluents have shown that they are environmental risks and potential mutagenic agents, problems still exist in the enforcement of on ground sound legislative by Federal Ministry of Environment and Federal Environmental Protection Agency. Failure in implementation of sound policies has been identified to be caused by weakness and poor enforcement by the necessary arms of the government, public awareness of international, national and local environmental laws. Legislation and standards that apply to existing and proposed projects are grossly lacking, the absence of mandatory disclosure of information by industries hinders monitoring which is a major problem to compliance and enforcement. Furthermore, there is absence of a legal framework which would ensure that industries comply with the requirement of standing environmental legislation. Any development that does not respect the environment cannot be said to be sustainable. There is therefore the need to integrate the environmental legislatives and environmental impact assessment (EIA) reports in the establishment and consequent monitoring of industries and industrial activities for the establishment and promotion of sustainable development and sound technologies.
\end{abstract}

Key words: Genotoxic, Allium test, industry, legislation, wastewater.

\section{INTRODUCTION}

The ever increasing growth and dependence of man on industries and industrial products certainly means great benefits to Nigeria and of course other countries of the world. The rapid and great strides in industrialization of the developing countries is a welcome development, however, most of these industries were sited with little or no consideration of the environmental and social consequences (Hussaini, 1997). It resulted in the discharge of potential mutagenic substances into the environment. Rank (2003) reported that genotoxic chemicals used for many purposes in manufacturing processes can be found in environmental compartments such as air, water, soil and sediments. These chemicals can enter the environment through untreated wastewater, air emissions and other means.

The problem of pollution in the third world is being further accentuated by the unharnessed sitting of Industrial sites and weakness in both implementation of environmental protection policies and subsequent monitoring of industrial wastes. In a bid to develop through 
industrialization, developing countries are constrained to pursue the same development models whose fall out assault and degrade the environment. How to develop creativity without compromising the native integrity of the environment now constitutes a major challenge (Anago, 2002). Nigeria is privileged to have an arm of the legislative whose mandate is environmental protection. This arm is called Federal Environmental Protection Agency (FEPA); now under Federal Ministry of Environment. So the policies guiding the industries in relation to the generated wastes are on ground. However these sound policies have problems at both implementation and enforcing the compliance.

Anago (2002) stated that the challenge is crucial because Nigeria, like most developing countries has world class legislation on various issues which nevertheless suffers failure at the implementation stage. In line with the above, Ogah (2005) reported policy-related weaknesses and poor enforcement by the necessary arms of the government. Based on the foregoing, Industries are established without prior assessment of environmental consequences of the envisaged project.

It is well established that pollution lowers the quality of life in various aspects (El-Shahaby et al., 2003). Odeigah et al. (1997) reported that of the major economic sectors, the ones most vulnerable to environmental pollution or degradation are agriculture and fisheries, mainly because they are directly dependent on natural systems and resources. Grover and Kaur (1999) reported that besides the direct health effects, the subtle danger of pollutant lies in the fact that they may be mutagenic or toxic and lead to several human afflictions like cancer, cardiovascular diseases and premature aging. Waste waters are extremely complex, this makes it difficult to carry out a hazard assessment based on chemical analysis only (El-Shahaby et al., 2003). These waste waters are complex mixtures, often times with high concentrations of potentially mutagenic heavy metals and cyanides. Heavy metals are implicated as environmental risk.

Plants comprise a large portion of the biosphere and constitute a vital link in the food chain. Due to the highly conserved structure of their genetic material, it is possible to use a broad variety of species in genotoxicity tests. Several higher plant bioassays for screening environmental mutagens have been established (Maluszynaska and Juchimiuk, 2005). The common onion, A. cepa L. makes a convenient test system for estimating harmful effects of chemical on biological materials (Fiskesjo, 1985, 1993; Rank and Nielsen, 1998). The Allium genetic material has been widely exploited for such purposes. Plant roots are very useful in this testing because the root tips are often the first to be exposed to chemicals in the soil and water (Odeigah et al., 1997). Many new mutagenicity assays using other test systems, microorganism, mammalian cells and other biological systems have been developed but plant tests which have high correlation with other test systems are used routinely for genotoxicity testing all over the world (Fiskesjo and Levan, 1993; Grant, 1999).

Most industrial wastewater can be characterized as extremely complex mixtures containing numerous inorganic and organic compounds (Nielson and Rank, 1994). Most of these effluents contain high concentrations of potentially mutagenic heavy metals (Abu and Egeugwu, 2008). Ivanova et al. (2005) reported that heavy metals are among the most toxic and environmentally dangerous pollutants. Dovgaliuk et al. (2001) has shown that heavy metals could induce clastogenic and aneugenic effects including mitosis and cytokinesis disturbances. The concentration of the heavy metal ions in some water samples may seem low, yet they have tremendous deleterious effects on living systems. This could be attributed to bioaccumulations and bio-reactions.

This article is aimed at reviewing positive results of cytotoxicity and genotoxicity assays and problems of effective compliance to Federal environmental policies and environmental impact assessment (EIA) recommenddations in Nigeria.

\section{MATERIALS AND METHODS}

An in-depth literature research was made from the internet and serial materials of Nnamdi Azikiwe e-library, University of Nigeria, Nsukka. Various journal articles, proceedings of learned society of Genetics, congress papers and textbooks were consulted with regard to industrial effluent, environmental protection policies, cytotoxicity and genotoxicity of these effluents on $A$. cepa genetic material. The data collected were presented in tables and figures.

\section{RESULTS}

Heavy metals have been found to be present in most wastewaters. The concentration of heavy metals in wastewater from diverse industrial sites has been reported by authors from diverse background. ElShahaby et al. (2003) reported a range of 0.29 to 0.43 $\mathrm{mg} \mathrm{l}^{-1}$ for $\mathrm{Pb} ; 0.10$ to $0.22 \mathrm{mg} \mathrm{l}^{-1}$ for $\mathrm{Zn} ; 0.20$ to $0.40 \mathrm{mg} \mathrm{l}^{-1}$ for $\mathrm{Cu} ; 0.10$ to $0.15 \mathrm{mg} \mathrm{l}^{-1}$ for $\mathrm{Cd}$ and 0.2 to $0.40 \mathrm{mg} \mathrm{l}^{-1}$ for Co as the composition of wastewater from four sites along the course of the new Mansoura drain. Most of these wastewaters from Nigeria factories have been found to contain potentially mutagenic heavy metals at concentrations higher than the recommended environmental standards by the Federal Environmental Protection Agency of Nigeria (Tables 1 to 3). The concentrations of lead $(\mathrm{Pb})$ in diverse analyses of effluents from different sources in Nigeria and other countries ranged from 0.29 to $0.43 \mathrm{mg} \mathrm{l}^{-1}$ (El-Shahaby et al., 2003), $2.31 \mathrm{mg} \mathrm{I}^{-1}$ in wastewater from insecticidal and shoe polish factory (Abu and Ezeugwu, 2008), 2.82 to 44.043 $\mathrm{mg} \mathrm{I}^{-1}$ in soap and cosmetic industrial effluent (Abu and Ogbonna, 2009; FEPA 1991), 0.5 to $2.243 \mathrm{mg} \mathrm{l}^{-1}$ in diverse 
Table 1. Chemical analysis of wastewaters and the Nigeria environmental standard (Abu and Mba 2011).

\begin{tabular}{|c|c|c|c|c|c|c|c|c|}
\hline Effluent and standard & pH & TDS $\mathrm{mg} \mathrm{l}^{-1}$ & Cu mg I ${ }^{-1}$ & $\mathrm{Zn} \mathrm{mg} \mathrm{^{-1 }}$ & $\mathrm{Pb} \mathrm{mg} \mathrm{l}^{-1}$ & $\mathrm{Cl} \mathrm{mg} \mathrm{I}^{-1}$ & $\mathrm{SO}_{4} \mathrm{mg} \mathrm{l}^{-1}$ & Cn mg I ${ }^{-1}$ \\
\hline Jutrim & 2.9 & 42,000 & 20.0 & 17.3 & 2.2 & 0.02 & 696.2 & 0.09 \\
\hline Flu-J & 2.8 & 14,000 & 8.5 & 117.6 & 0.05 & 0.03 & 56 & 0.04 \\
\hline Ampiclox & 4.1 & 12,00 & 6.0 & 147.6 & 1.23 & 0.01 & 79 & 0.07 \\
\hline Nigerian Standard & $6-9$ & 2,000 & $<1$ & - & $<1$ & 600 & 500 & - \\
\hline
\end{tabular}

Table 2. Chemical analysis of wastewaters and the Nigeria environmental standard (Abu and Ezeugwu, 2007).

\begin{tabular}{lcccccccccccccc}
\hline Wastewater & pH & TDS & $\mathbf{S O}_{4}$ & $\mathbf{C l}$ & COD & TSS & Na & K & Ca & Mg & Co & Cu & Cd & Ph \\
\hline Nigerian Standard $^{*}$ & $6-9$ & 2,000 & 500 & 600 & - & 30 & - & - & 3 & 200 & - & $<1$ & $<1$ & $<1$ \\
Wastewater & 6.3 & 520 & 71.7 & 90 & 512 & 14,700 & 275 & 42.5 & 1,062 & 48.6 & 18.86 & 1191.12 & 43.76 & 2.31 \\
\hline
\end{tabular}

Table 3. Chemical analysis of wastewaters and the Nigeria environmental standard (Abu and Ogbonna, 2008)

\begin{tabular}{lccccccccccc}
\hline Wastewater & $\mathbf{p H}$ & $\mathrm{EC}$ & $\mathrm{Cl}$ & $\mathrm{SO}_{4}$ & $\mathrm{Na}$ & $\mathbf{C a}$ & $\mathbf{M g}$ & $\mathrm{Co}$ & $\mathrm{Cd}$ & $\mathrm{Cu}$ & $\mathrm{Pb}$ \\
\hline Soap & 10.4 & 140 & 1485 & 8.6 & 4000 & 24.1 & 97.3 & 9.43 & 25.58 & 657.67 & 44.0 \\
Cosmetic & 7.1 & 22 & 114 & 0.9 & 75 & 114.2 & 145.9 & 25.93 & 29.28 & 847.66 & 2.82 \\
Nigeria standard $^{*}$ & $6-9$ & - & 600 & 500 & - & 3 & 200 & - & $<1$ & $<1$ & $<1$ \\
\hline
\end{tabular}

pharmaceutical effluents (Abu and Mba, 2011). Cadium (Cd) ranged from 0.1 to $0.1543 \mathrm{mg} \mathrm{l}^{-1}$ (El-Shahaby et al., 2003), $43.843 \mathrm{mg} \mathrm{l}^{-1}$ (Abu and Ezeugwu, 2008), 25.58 to 29.28 (Abu and Ogbonna, 2009). Copper was also found to be higher than the recommended environmental safe levels (Tables 1 to 3 ). The concentrations of other chemical substances such as sulphate and cyanide were higher than the recommended environmental safe standards (Tables 1 to 3 ). The ionic concentrations $(\mathrm{pH})$ of wastewaters from some industries are often times more acidic than the recommended environmental levels.

The macroscopic analysis of the root growth of $A$. cepa used in the assay for general toxicity showed strong growth retardation at high concentrations of the oil field wastewater (Odeigah et al., 1997). Total phytotoxic effects (complete inhibition of root growth) were recorded in undiluted oil field water (Odeigah et al., 1997) and in both diluted and undiluted soap industrial wastewater (Abu and Ogbonna, 2009). The sigmoid curve of root length as a percentage of the control is a typical doseresponse curve for this kind of toxic effects (Rank, 2003). The effects on root growth are as shown in Figures 1 to 3 (Odeigah et al., 1997; Abu and Mba, 2011).

The effluents suppressed root growth in $A$. cepa as shown by their effects on both root growth and number of roots per bulb (Figures 1,2 and 3). Root growth as assessed by the number of roots in pharmaceutical effluents ranged from 109 to $5.3,93$ to 20.4 and 122 to 8.3 in Jutrim, Flu-J and Ampiclox effluents, respectively
(Figure 2). The drastic decline from the control to undiluted wastewater can be easily observed. Diverse reports on the toxicity of industrial wastewater have shown that their effects on mitotic index (MI) are dose dependent, reducing the MI values as the concentrations increase (Figure 2) (Odeigah et al., 1997; Samuel et al., 2010; Abu and Mba, 2011).

Abu and Ezeugwu (2008) observed that the MI (\%) estimated in $50 \%$ concentration of the wastewater was found to be higher than the Ml estimated in the control (Figure 4). However, on a closer observation of the cells, most of the dividing cells at $50 \%$ effluent concentration were abnormal (Figure 5). The root cells on coming in contact with the wastewater seemed to have started dividing faster but abnormally. This seems to suggest a kind of cancerous growth effects of the wastewater on bio-life. Equally, some researchers integrated the data on mitotic progress to include data on mitotic stages in their report (Abu and Ezeugwu, 2008; Abu and Ogbonna, 2008). The authors reported accumulation of cells at prophase stage, commonly called prophase accumu-lation. This implies that the number of dividing cells often used to estimate the MI may majorly be in prophase stage. This has been said to be a common deleterious effect of industrial wastewater and other complex mixtures on the root tip meristems of plant materials (Raji and Reddy, 1971).

Prophase accumulation has been attributed to a delay in the breakdown of the nuclear membrane due to "carry 


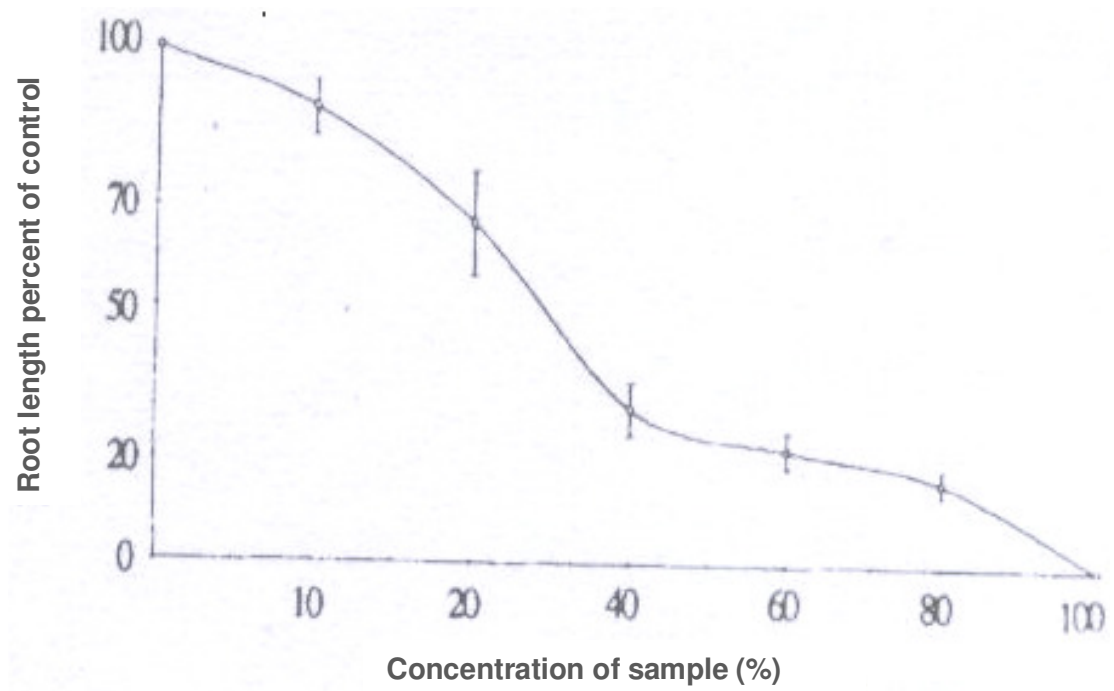

Figure 1. Growth curve of Allium roots (in relation to control) after treatment with oil field wastewater (the curve plotted by a computer is based on mean values with the $95 \%$ confidence intervals shown as error bars).

Source: Odeigah et al. (1997).

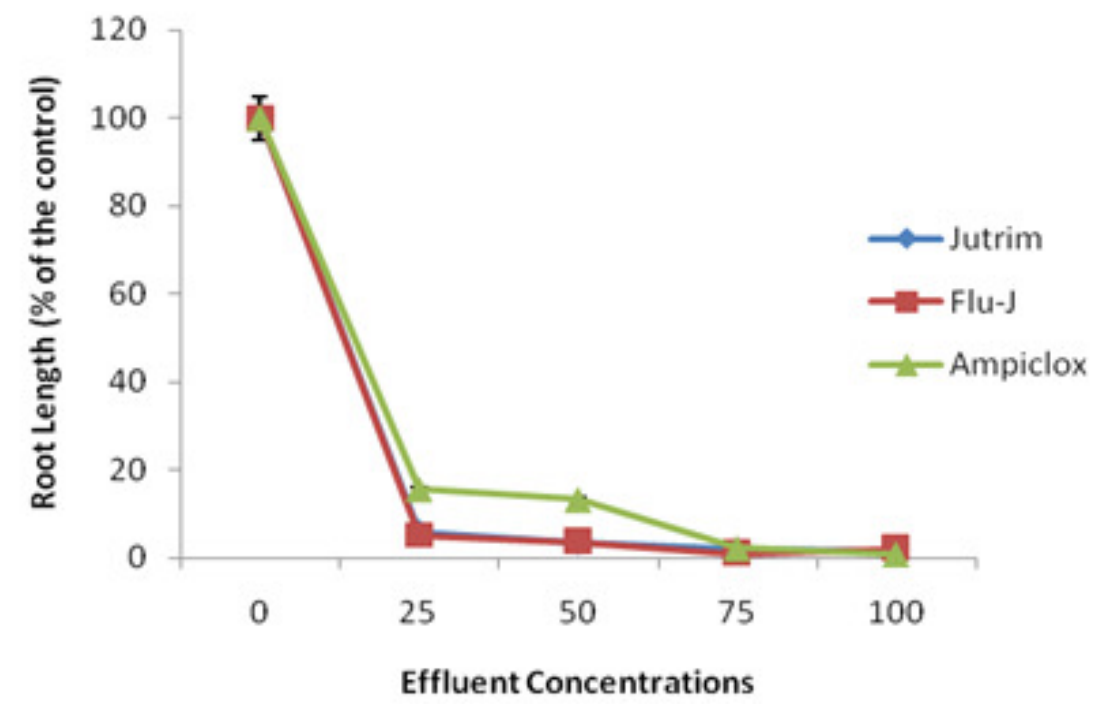

Figure 2. Root length as a percentage of the control in the three effluents and their dilutions.

Source: Abu and Mba (2011).

over' inhibitory effects of treatments from interphase stage (Wilson, 1965). However, Ene-Obong and Amadi (1987) and Amor and Farah (1974) attributed prophase accumulation to spindle abnormalities. Conversely, the number of abnormal dividing cells increased as the effluent concentrations increased (Figure 5). This implies that the wastewater is more deleterious at the point of discharge on water bodies and on contact organisms on soil, if there were no natural sources of dilution.

Industrial effluents induced chromosomal aberrations in root tip cells of $A$. cepa in the form of vagrant chromosomes, C-mitosis, anaphase and telophase bridges and cytokinetic failures. The abnormalities at the nuclear level include binucleated (or binuclei) cells Figure 6, elongated nucleus with nuclear wall lesions (Figure 7). All these irregularities in cell reproduction could lead to diverse 


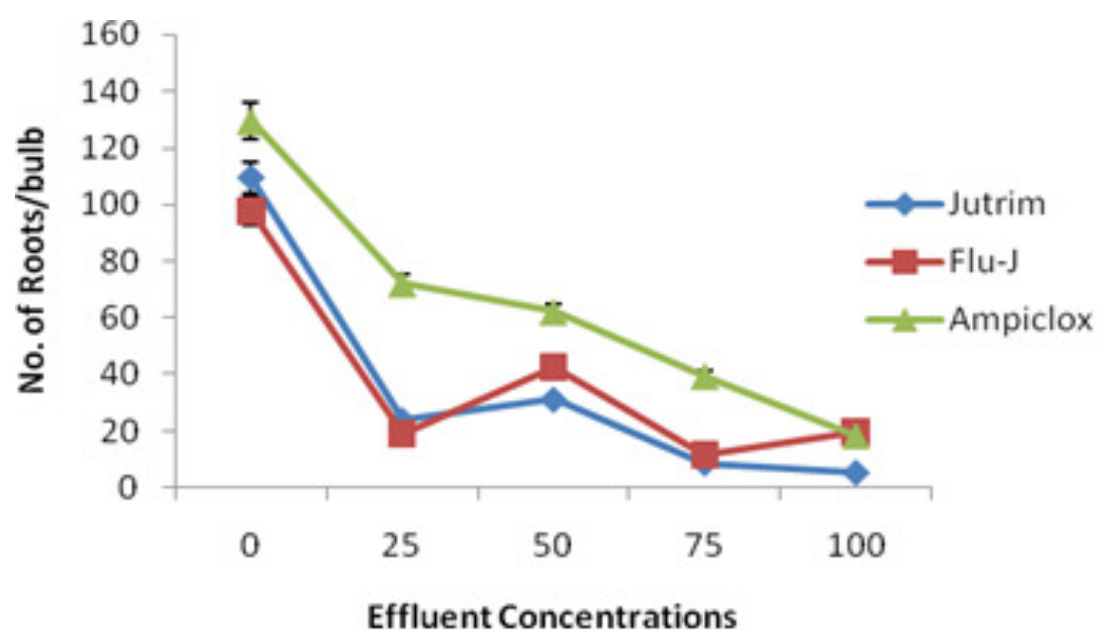

Figure 3. Number of roots per bulb in the three effluents and their dilutions. Source: Abu and Mba (2011).

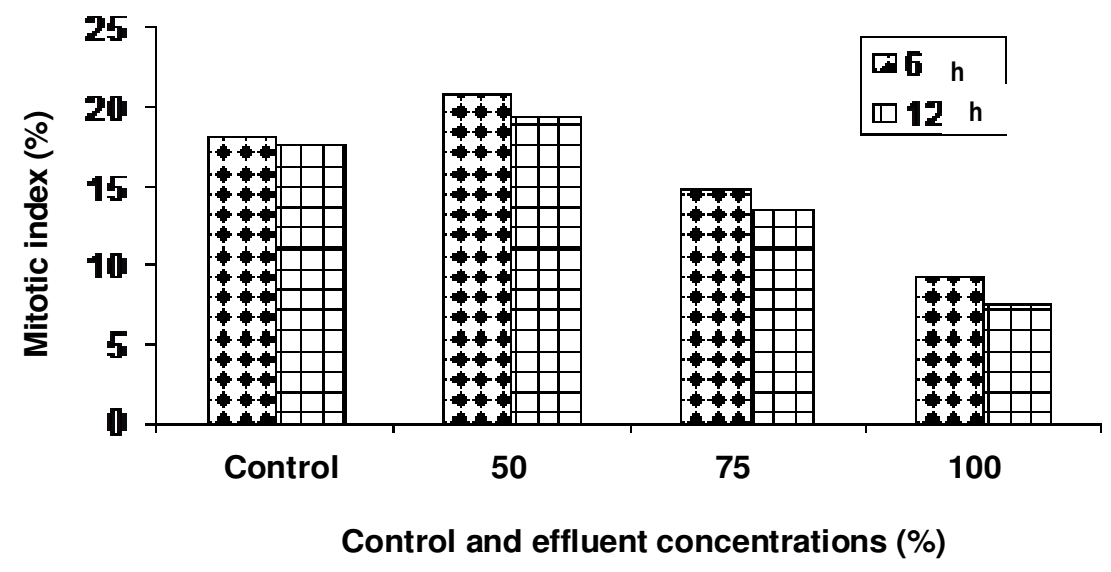

Figure 4. Mitotic index at different effluent concentrations. Source: Abu and Ezeugwu (2008).

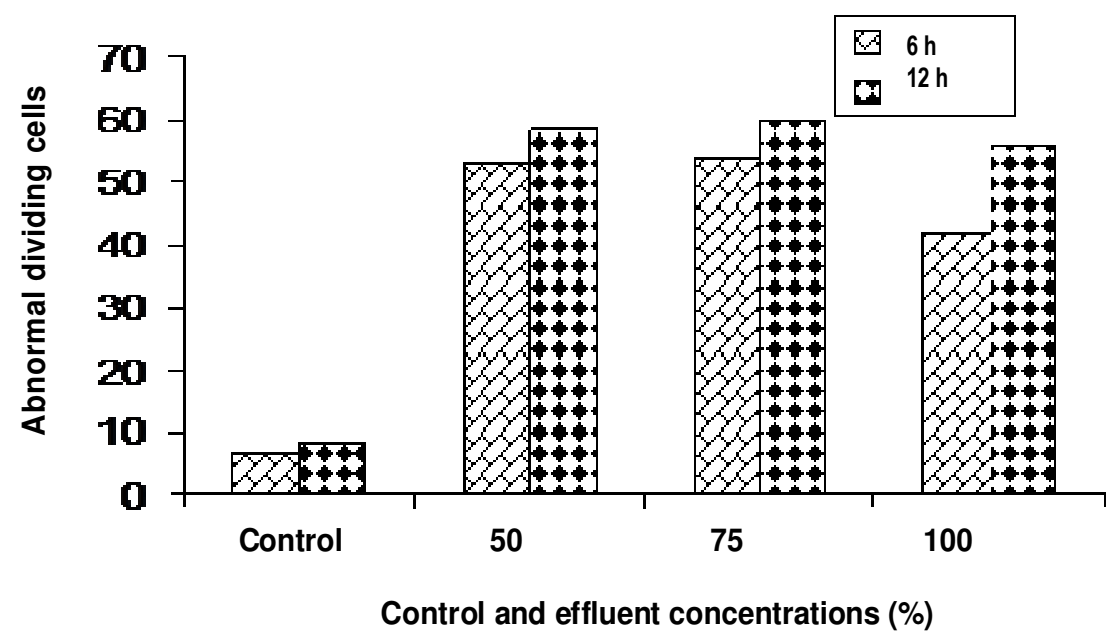

Figure 5. Abnormal dividing cells atdifferne effluent concentrations. Source: Abu and Ezeugwu (2008). 

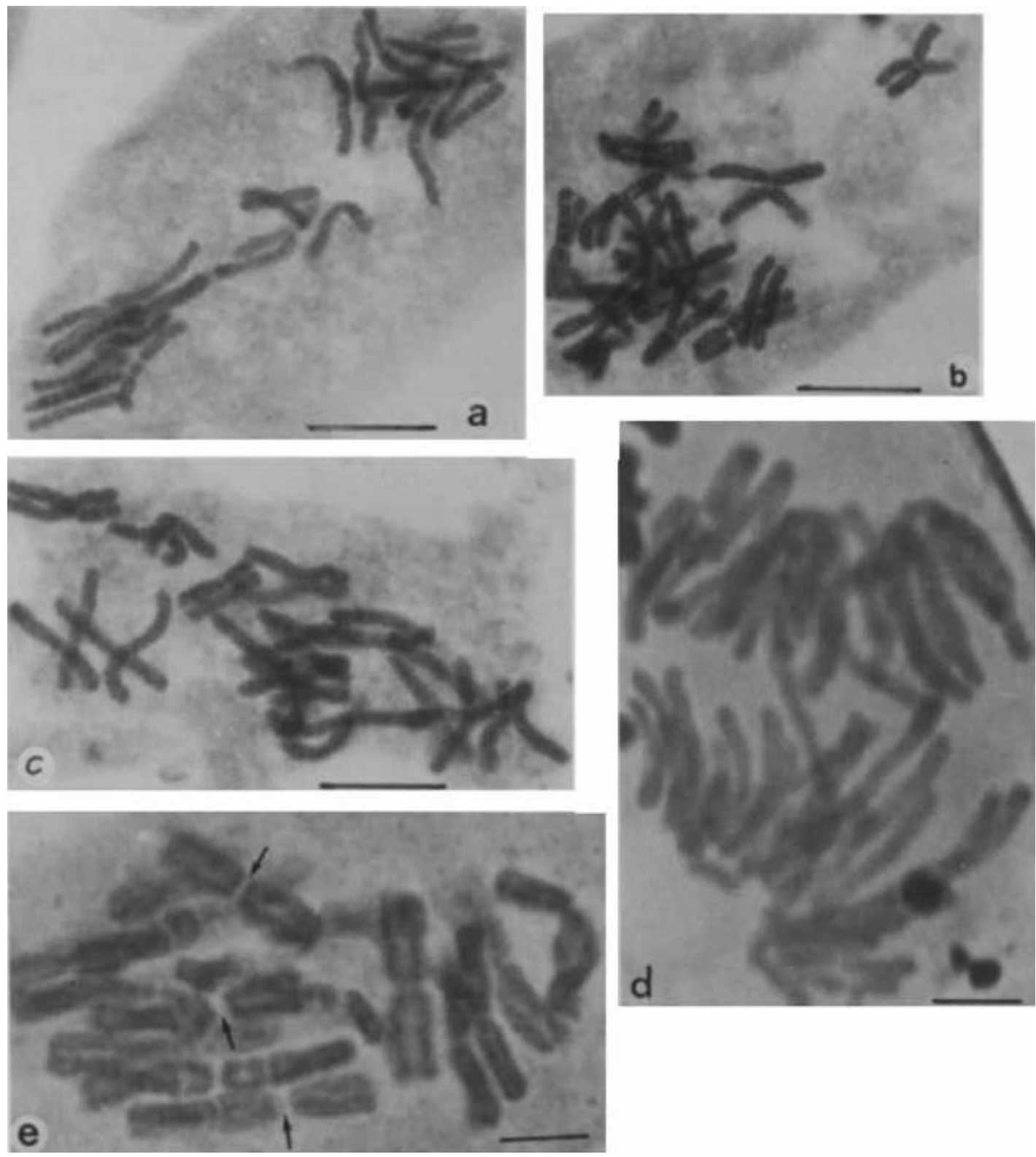

Figure 6. Mitotic aberrations caused by oil field waste water. (a) C-anaphase with laggards (20\% concentration), (b) vagrant chromosome (10\% concentration), (c) C-metaphase, (d) multipolar anaphase with bridges and fragments (40\% concentration), (e) C-metaphase chromosomes, three instances arrowed with enlongated centromeres. Scale $=10 \mu \mathrm{m}$ Source: Odeigah et al. (1997).

forms of mutation and chromosomal aberrations. Cmitotic effects on cells have been attributed to spindle abnormalities (Grover and Kaur, 1999). Abnormal spindle function and inhibition of cytokinesis were equally observed by Panda and Sahu (1985). Kovalchuk et al. (2001) stated that pollution with heavy metal salts caused an increase in the frequency of somatic intrachromosomal mutations.

\section{DISCUSSION}

Most wastewaters are discharged as effluents with heavy industrial load of salts and heavy metals. Industrial effluents are the main source of direct and often continuous input of pollutants/toxicants into aquatic ecosystems with long-term implications on ecosystem functionning (Odeigah and Osanyinpeju, 1995; Chan et al., 2003; 


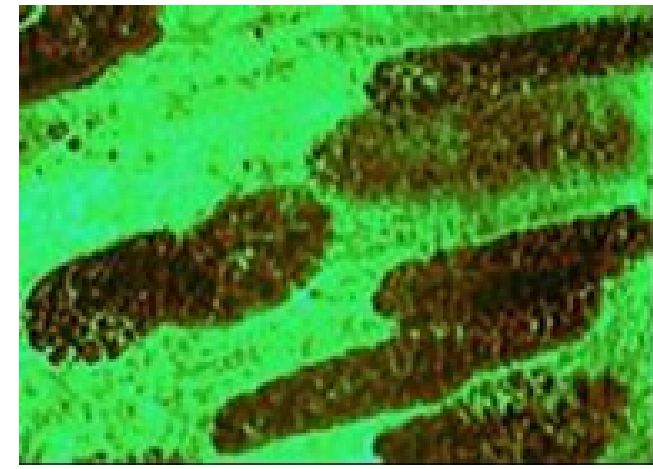

(a)

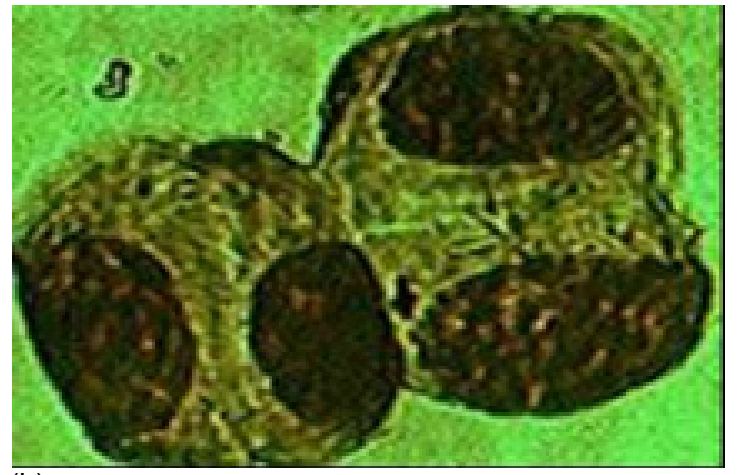

(b)

Figure 7. Abnormal nuclei. (a) Enlongated nuclei with nuclear wall leisons, (b) binucleate cells. Source: Abu and Mba (2011).

Smolders et al., 2004). The heavy metals and cyanide that are present in industrial effluents are potentially mutagenic substances that would eventually find their way into man through diverse sources as water bodies, plants and fisheries. Most industrial wastewater can be characterized as extremely complex mixtures containing numerous inorganic as well as organic compounds (Nielsen and Rank, 1994). Monitoring of hazardous wastes is vital for sustaining the required legalcompliances and in preventing irreversible health and ecological damages. However, the deleterious effects of heavy metals, organic and inorganic salts present in wastewater, together with other physicochemical components cannot be adequately assessed with chemical analysis only. Often, the action cannot be attributed to specific compounds in the mixture but to a set of chemical properties and interactions of the sample as a whole (Vargas et al., 1993).

Among the bioassays developed for detection of mutagenicity, genotoxicity and cytotoxicity due to wastewaters and other environmental pollutants, plants system have proven to be sensitive, cheap and effective (Gopalan, 1999; Grant, 1999), plant roots are generally used in bioassays because they are the first structures to be exposed to chemicals in both water and soil (Fiskesjo, 1988; Odeigah et al., 1997). Fiskesjo and Levan (1993) reported that Allium test has high correlation with other test systems (MIT-217 cell test with mice, rats or humans in vivo) and could be used as an alternative to laboratory animal in toxicological research. This implies that the deleterious effects observed in plant genetic materials could also be similarly observed in man and other animals. The modified Allium test involves the macro assay of the root growth parameters and the micro assay of the Allium genetics material (Rank, 2003).

Having established that these pollutants find their way into man and other animals (Njagi and Gopalan 1981), it becomes very necessary to enforce environmental legislation. Yet in a bid to develop through industrialization, developing countries are constrained to pursue the same development models whose fall out assault and degrade the environment (Anago, 2002). It is necessary to meet developmental and environmental needs of the present and future generation. Environmental Impact Assessment (EIA) is the perceived tool for achieving this purpose. Nigeria is one of the few developing countries that have specific relevant legislation on EIA (Anago, 2002).

One of the basic principles for the achievement of environmentally sound and sustainable development is the development and proper application of legal instruments in the field of environment (Nwafor, 2006). The results of diverse assessments of industrial effluents, chemical and biological assays, have shown that they are environmental risks; yet problems exist in the enforcement of on ground sound legislative by federal ministry of environment, partly due to problems in the legal framework and weakness and/or inadequacies challenging the ministry.

Equally, public awareness of international, national and local environmental laws, legislation and standards applied to existing and proposed projects are grossly lacking. Most part of the population do not even know how and where to address the challenging issues of wastewater discharge into their water bodies and farmlands. Umeh and Uchegbu (1997) reported that the objectives and advantages of EIA need to be communicated in comprehensive terms to the community. The adverse and beneficial effects should be identified on the basis of criteria relevant to the countries affected. EIA teams have the responsibility to communicate effectively with a very diverse audience (Nwafor, 2006). The few members of the community that have the knowledge of environmental legislatives and Non-Governmental Organizations (NGO's) are facing serious resistance from the industrialists on matters of enforcement. 
A typical example would be the report of Anago (2002) about the Kaduna industrial complex, where textile mills were established to encourage industrialization and provide employment; however, the cluster of mills presently constitutes environmental nuisance and a core source of water pollution. The same author reported that several attempts by the host community and NGO's to force a change in the indiscriminate discharge of industrial effluent and toxic waste into River Kaduna (the only source of portable water supply) has largely failed.

In recent times, environmental policies are made with the aim of integrating development programmes with environmental issues at the planning stage. The proprietors of industries, especially those industries established before these environmental policies were made, consistently resist change to cleaner technologies. Some of these industrialists argue that such change involves heavy financial expenditure that would render their operation less profitable (Anago, 2002).

Having identified wastewaters as being an environmental risk and capable of causing diverse human afflictions, industries/industrialists need to be compelled by legal means to change their operations to environmentally sound technologies. Nwafor (2006) identified the absence of mandatory disclosure of information by industries, which hinder monitoring as part of the problems of effective compliance and enforcement. The author further stated that the absence of a legal framework, which would ensure that industries comply with the requirements for compliance in respect of pollution abatement standards, is a major obstacle to environmental enforcement. In stressing the importance of monitoring, Ogbuigwe (1996) reported that a standard is not meaningful unless it can be established, whether the actual level of performance is above or below the standard and by how much it deviates from the standard. When these observations are placed against the current situation in Nigeria, where there is no legal arrangement to guarantee public access to information on compliance and monitoring of industries and facilities, then the seriousness of the obstacles, which hinder enforcement, are fully appreciated.

Industrialization is wholly considered as a key indicator of development; however, the industrially generated wastes could cause diverse occupational risks. There is urgent need to ensure the implementation and/or compliance of existing environmental legislations, especially in Nigeria, where majority of the population depends on streams, river and other natural water sources for drinking and household uses. Any development that does not respect the environment cannot be said to be sustainable.

Having identified diverse pitfalls of the enforcement of untreated wastewater discharge into the ecosystem, and having fully discussed their health risk on man and the ecosystem in general, It is therefore necessary to enforce periodic monitoring on existing industries and integrate environmental policies prior to the establishment of new industries, in order to achieve environmentally sound technologies for sustainable development.

\section{REFERENCES}

Abu NE, Mba KC (2011). Mutagenecity testing of pharmaceutical effluents on Allium cepa root meristems. J. Toxicol. Environ. Health Sci. 3(2):44-51.

Abu NE, Ogbonna OH (2009). Cytotoxicity and genotoxicity screening of industrial wastewater: A case study of Cosmetics and Soap industrial effluents. Biores. 7(2):534-539

Abu NE, Ezeugwu SC (2008). Risk evaluation of industrial wastewater on plants using onion (Allium cepa) chromosome aberration assay. Agro Sci. 7(3):242-248.

Amor SM, Farah OR (1974). Cytololgical Effects of Insecticide 'Rogor' on the Mitosis of Vicia faba and Gossypium barbadense. Cytologia 39:507-514.

Anago IT (2002). Environmental Impact assessment as a tool for sustainable development: The Nigerian experience. In: FIG XXII International congress, Washington DC, USA. pp. 1-13. Available at: www.fig.net/pub/fig_2002/ts10-3/ts10_3_anagopdf.

Chan YK, Wong CK, Hesieh DPH, Ng SP, Lau TK, Wong PK (2003). Application of a toxicity identification evaluation for a sample of effluent discharged from a dying factory in Hong Kong. Environ. Toxicol. 18:312-316.

Dovgaliuk, Al, Kaliniiak TB, Blium B (2001). Assessment of phyto- and cyto- toxic effects of heavy metals and aluminum compounds using onion apical meristem. Tsitol. Genet. 35:3-9.

El-Shahaby OA, Abdel HM, Soliman MI, Mashaly IA (2003). Genotoxicity screening of industrial wastewater using the Allium cepa chromosome aberration assay. Pak. J. Biol. Sci. 6(1):23-28.

Ene-Obong EE, Amadi OC (1987). Contributions to the Cytological Effects of Medicinal Plants- 1. The Mitodepressive Effects of Water Extracts of Boerharvia diffusa and Vernomia amygdalina on Allium cepa root tip mitosis. Cytologia 52: 469-474.

Fedral Environmental Protection Agency FEPA (1991). Guidelines and standards for environmental control in Lagos, Nigeria. In : Umeh IC, Uchegbu SN (1997) (Eds.), Principles and procedures of environmental impact assessment (EIA). Amazing Grace Printing and Publishing Company, Lagos. pp. 167.

Fiskesjo G (1985). Allium test on river water from Braan and Sexan before and after closing of a chemical factory. Ambio 14: 99-103.

Fiskesjo G (1988). The Allium Test - an alternative in environmental studies: The relative toxicity of metal ions. Mutat. Res. 197: 243-269.

Fiskesjo G (1993). The Allium Test in waste water monitoring. Environ. Toxicol. Water Qual. 8(3):291-298.

Fiskesjo G, Levan A (1993). Evaluation of the first ten MEIC chemicals in the Allium test . Altern. Lab. Anim. 21:139-149.

Grant WF (1999). Higher plant assays for the detection of chromosomal aberrations and gene mutations: A brief historical background on their use for screening and monitoring environmental chemicals. Mutat. Res. 426:107-112.

Gopalan HN (1999). Ecosystem health and human wellbeing: The mission of the international programme on plant bioassays, Mutat. Res. 426(2):99-102.

Grover IS, Kaur S (1999). Genotoxicity and wastewater samples form sewage and industrial effluent detected by the Allium root anaphase aberration and micronucleus assays. Mutat. Res. 426:183-188.

Hussaini I (1997). Environmental impact assessment procedures. In: Anago IT (ed.), Environmental Impact assessment as a tool for sustainable development: The Nigerian experience, FIG XXII International Congress, Washington DC, USA. pp. 1-13. Available at: www.fig.net/pub/fig_2002/ts10-3/ts10_3_anagopdf.

Ivanova E, Staikova TA, Velcheva I (2005). Cytogenetic testing of heavy metal and cyanide contaminated river waters in a mining region of South Bulgaria. J. Mol. Cell Biol. 4:99-106. 
Kovalchuk O, Titov V, Hohn B, Kovalchuk J (2001). A sensitive transgenic plant system to detect toxic inorganic compounds in the environment. Nat. Biotechnol. 6:568-572.

Maluszynaska J, Juchimiuk J (2005). Plant genotoxicity: A molecular and cytogenetic approach in plant bioassays. J. Toxicol. Environ. Health Sci. 56:177-184.

Nielson MH, Rank J (1994). Screening of toxicity and genotoxicity in wastewater using Allium test. Heriditas 121:249-254

Nwafor JC (2006). Environmental impact assessment for sustainable development: The Nigeria Perspective. Environment and Development Policy Centre for Africa (EDPCA) Publications, Enugu. $658 \mathrm{p}$.

Njagi GD, Gopalan, HNB (1981). Mutagenicity Testing of Herbicides, Fungicides and Insecticides 1. Chromosome Aberrations in Vicia faba. Cytologia 46:169-172.

Odeigah PGC, Nurudeen O, Amund OO (1997). Genotoxicity of oil field wastewater in Nigeria. Hereditas 126:161-167.

Odeigah PGC, Osanyinpeju O (1995). Genotoxic effects of two industrial effluents and ethylmethane sulfonite in Clarias lazera. Food Chem. Toxicol. 33:501-505.

Ogah F (2005). Nigerian genetic resources: Conservation, management and sustainable use. Proceedings of the 30th Annual Conference of GSN, University of Nigeria, Nsukka. pp. 5-12.

Ogbuigwe A (1996). Report on the review of environmental protection agency in Enugu State. In: Nwafor JC, Environmental impact assessment for sustainable development: The Nigeria Perspective. Environment and Development Policy Centre for Africa (EDPCA) Publications, Enugu. 658 p.

Panda BB, Sahu UK (1985). Induction of abnormal spindle function and cytokinesis inhibition in mitotic cells in Allium cepa by organophosphorus insecticides fensulfothion. Cytobios 42:147-155.
Raji AS, Reddy SS (1971). Cytological studies in Vicia faba L. treated with leaf of two varieties of Lathryrus sativas. Cytologia 36:702-715.

Rank J (2003). The method of Allium anaphase: Telophase chromosome aberration assay. Ekologiia 1:38-42.

Rank J, Nielson MH (1998). Genotoxicity testing of wastewater sludge using the Allium cepa anaphase-telophase chromosome aberration assay. Mutat. Res. 418:113-119.

Samuel OB, Osuala FI, Odeigah PGC (2010). Cytogenotoxicity evaluation of two industrial effluents using Allium cepa assay. Afr. J. Environ. Sci. Technol. 4(1):21-27.

Smolders R, Bervoets L, Blust R (2004). In situ and laboratory bioassays to evaluate the effects of effluents discharges on receiving aquatic ecosystem. Environ. Pollut. 132(2):231-243.

Umeh IC, Uchegbu SN (1997). Principles and procedures of environmental impact assessment (EIA). Amazing Grace Printing and Publishing Company, Lagos. 167p.

Vargas VM, Molla VE, Henriques JA (1993). Mutagenic activity detected by the Ames test in river water under the influence of petrochemical industries. Mutat. Res. 319:31-45

Wilson GB (1965). The Assay of Antimitotics. Chromosoma (Bert). 16:133-143. 